\title{
A southern species of the tropical catfish genus Phractocephalus (Teleostei: Siluriformes) in the Miocene of South America
}

\author{
María de las Mercedes Azpelicueta ${ }^{a, *}$, Alberto Luis Cione ${ }^{\mathrm{b}}$ \\ a División Zoología Vertebrados, Museo de La Plata, 1900 La Plata, Argentina \\ b División Paleontología Vertebrados, Museo de La Plata, 1900 La Plata, Argentina
}

\section{A R T I C L E I N F O}

\section{Article history:}

Received 1 December 2015

Received in revised form

19 February 2016

Accepted 1 March 2016

Available online 7 March 2016

\section{Keywords:}

Cenozoic

Phractocephalus ivy

Pimelodidae

Argentina

Entre Ríos

\begin{abstract}
A B S T R A C T
Catfish bones from Tortonian (Miocene) freshwater beds of central Argentina are here identified as pertaining to a new species of the tropical pimelodid genus Phractocephalus. The new species differs from the other recent and fossil species of the genus in skull, pectoral girdle and spine characters. The material was found in different localities near the city of Paraná, Entre Ríos Province. The bearing horizon is the so-called "Conglomerado osífero" which constitutes the lowermost beds of the fluvial Ituzaingó Formation. The aquatic vertebrate fauna occurring in the bearing bed shows a similar generic composition to several northern South American Miocene units where Phractocephalus remains were found. This report extends the range of Phractocephalus more than $2000 \mathrm{~km}$ to the South. The record is in agreement with higher global temperatures and putative ample hydrographic connections of the river basins in the Paraná area with the Amazon basin until at least the early late Miocene.
\end{abstract}

๑) 2016 Elsevier Ltd. All rights reserved.

\section{Introduction}

Siluriformes is one of the most diversified freshwater fish orders. The group is widely distributed in freshwater of all continents except Antarctica although there are some marine and amphibiotic species (Berra, 2001). The fossil diversity is poor (Malabarba and Malabarba, 2010) in comparison with the present species richness that has been calculated ranging to 3700 (Eschmeyer and Fong, 2015). However, the information obtained from fossil specimens is relevant for understanding the evolution and biogeographical history of the group (e.g. Aguilera et al., 2008; Azpelicueta and Cione, 2011; Azpelicueta et al., in press; Grande, 1987; Lundberg and Aguilera, 2003).

Fishes of the order occupy very different ecological niches (Lowe-McConnell, 1987). The large redtail catfish Phractocephalus hemioliopterus (Spix von and Agassiz, 1829) is among the most conspicuous fishes in Amazonas, Essequibo, Araguaia-Tocantins, and Orinoco river basins (Lundberg et al., 2010; Souza et al., 2012). Phractocephalus is known as cajaro in Venezuela and pirarara in Brazil. Redtail catfish is included in the family Pimelodidae (Lundberg and Littman, 2003). Two fossil species are known so far,

\footnotetext{
* Corresponding author.

E-mail addresses: azpeli@fcnym.unlp.edu.ar (M.M. Azpelicueta), acione@museo. fcnym.unlp.edu.ar (A.L. Cione).
}

both from Late Miocene beds: P. nassi Lundberg and Aguilera, 2003 from the Urumaco Formation of Venezuela and P. acreornatus (Aguilera et al., 2008) from the Solimões Formation of Western Brazil. Besides, indeterminate remains of Phractocephalus are known from the Middle Miocene Honda Group of Colombia (Lundberg et al., 2010).

Since D'Orbigny visited the area in the first half of the XIX century, many Argentinean and foreign paleontologists collected animal and plant remains in the Miocene beds outcropping in the east Paraná riverside near the city of Paraná of the Entre Ríos province in central-eastern Argentina. One of the authors identified many bones assignable to the genus Phractocephalus in collections of the Museo Argentino de Ciencias Naturales "Bernardino Rivadavia" of Buenos Aires and the Museo de La Plata. We collected additional material of Phractocephalus bones from the base of the Ituzaingó Formation. In this paper we describe the remains, compare them with recent and fossil species, and briefly discuss the paleobiogeography.

\section{Material and methods}

The fossil material was prepared mechanically with needles and abrasive jets. The comparative recent material was cleared and counterstained following Taylor and Van Dyke (1985). Dry skeletons were also used. 
The examined fossil and recent specimens are housed in the following institutions: ANSP, Academy of Natural Sciences of Philadelphia, USA; CICYTTP-PV-P, Centro de Investigaciones Científicas y Transferencia de Tecnología a la Producción, Diamante, Argentina; FMNH, Field Museum of Natural History, Chicago, USA; MACN, Museo Argentino de Ciencias Naturales "Bernardino Rivadavia", Buenos Aires, Argentina; MLP, División Zoología Vertebrados, Museo de La Plata, La Plata; MZUSP, Museu de Zoologia da Universidade de São Paulo, São Paulo, Brazil. USNM, Smithsonian Institution, Washington, USA.

Anatomical abbreviations used are: boc, basioccipital; epi, epiotic; ex, extrascapula; exo, exoccipital; f, frontal; let, lateral ethmoid; mpl, middle pit-line; pas, parasphenoid; pro, prootic; pt, pterotic; pter, pterosphenoid; soc, parietosupraoccipital; sp, sphenotic.

Specimens of the following recent species were examined: Aguarunichthys torosus: MZUSP 50398, http://catfishbone.ansp.org. Bagropsis reinhardti: MZUSP 39671. Brachyplatystoma filamentosum: ANSP 187105. Bergiaria westermanni: FMNH 58251. Brachyplatystoma tigrinum: USNM 280746. Cheirocerus goeldii: ANSP 150162; USNM 376345. Duopalatinus emarginatus: FMNH 58002. Exallodontus aguanai: ANSP 178791. Hypophthalmus oremaculatus: MACN 3496. Iheringichthys megalops: FMNH 58243, FMNH 95520. Leiarius marmoratus: MZUSP 27492. Leiarius perruno: USNM 121189. Luciopimelodus pati: ANSP 178798; MLP uncatalogued disarticulated specimen in the paleontological collection. Megalonema argentina: USNM 181597. Parapimelodus valenciennis: ANSP 178800. Phractocephalus hemioliopterus: ANSP http://catfishbone. ansp.org; MZUSP 43459, MZUSP 21963; USNM 304882, USNM 343444. Pimelodina flavipinnis: ANSP 178794. Pimelodus albicans: ANSP 187383; MLP 8991, MLP several uncatalogued disarticulated specimen in the paleontological collection. Pimelodus altissimus: MZUSP 45516. Pimelodus argenteus: ANSP 181017; MLP 9302. Pimelodus maculatus: ANSP 181019, MLP numerous uncatalogued disarticulated specimens; MZUSP 78456. Pimelodus mysteriosus: ANSP 180506. Pimelodus platicirris: MZUSP 22559, MZUSP 22933. Pseudoplatystoma coruscans: MLP exhibition room. Rhamdia quelen: ANSP 141578; MLP several uncatalogued disarticulated specimens in the paleontological collection. Sorubim lima: MZUSP 7553. Sorubimichthys planiceps: ANSP http://catfishbone.ansp.org. Steindachneridion inscriptum: MZUSP 78463. Zungaro jahu: MLP exhibition room; MZUSP 22449.

\section{Geological setting}

The material here studied was collected by S. Roth and J. Sors Cirera at the beginning of the XX century in different localities in the Paraná riverside cliffs near Paraná, Entre Ríos Province, Argentina. According to our field experience, the fossils come from the locality Toma Vieja and other nearby sites located to the northeast of the city of Paraná, Entre Ríos Province, Argentina (Fig. 1 ; $31^{\circ} 41^{\prime} \mathrm{S} 60^{\circ} 28^{\prime} \mathrm{W}$ ) where ALC collected additional material. The fossil bearing bed is the "Conglomerado osífero" which is located at the base of the fluvial Ituzaingó Formation. The "Conglomerado osífero" is a basal conglomerate occurring in paleochannels excavated on the marine Paraná Formation (Aceñolaza, 2000; Brunetto et al., 2013, Fig. 2). It includes abundant vertebrate remains and is overlain by scarcely fossiliferous whitish to yellow brown sandstones and green mudstones.

Marine mammals occurring in the top of the Paraná Formation indicate a late Miocene age (Cione et al., 2000). Likewise, Sr isotope ages obtained from the Paraná Formation and the correlative Puerto Madryn Formation from Patagonia indicate a Tortonian age (Scasso et al., 2001; Pérez, 2013) as well as a date from the top of the correlative Yecua Formation of Bolivia (Uba et al., 2009). Mammals occurring at the base of the overlying Ituzaingó Formation are Huayquerian in age in the South American chronology (Brunetto et al., 2013; Brandoni, 2013; Cione et al., 2000; Cione and Tonni, 2005). The Huayquerian ranges from about $9 \mathrm{Ma}$ to about $6 \mathrm{Ma}$ with radiometric and magnetostratigraphic calibration in western Argentina (Tortonian, late Miocene). A continental PliocenePleistocene (Marplatan to Platan in the South American chronology) sequence overlies both units (Cione et al., 2000).

\section{Systematic paleontology}

SILURIFORMES sensu (Grande, 1987)

Pimelodidae sensu (Lundberg and Littman, 2003)

Phractocephalus (Spix von and Agassiz, 1829)

Type species. Phractocephalus bicolor (Spix von and Agassiz, 1829), by monotypy, a junior objective synonym of Silurus hemioliopterus Bloch and Schneider.

Diagnosis. Dermal bones of skull, opercle, interopercle, anterior and middle nuchal plates, pectoral girdle and spines covered by thin skin and extensively ornamented with a unique, coarse meshwork of reticulating ridges surrounding rounded pits and sometimes elongated ridges and sulci. Parietosupraoccipital posterior process distinctively expanded laterally and posteriorly behind occipital wall, extrascapulars and postemporalsupracleithra. Anterior and middle nuchal plates fused and expanded in the skin forming a massive bilobed bony casque in front of dorsal fin and ornamented as the skull roof. Lateral ethmoid and sphenotic broadly sutured behind eye, eliminating frontal bone from margin of skull roof. In post-juveniles anterior cranial fontanelle increasingly reduced to a narrow slit, small or closed foramen between frontal bones, or completely closed; posterior cranial fontanelle closed. Vomerine tooth plate massive in size, roughly pentagonal to triangular in form, and covered with very fine teeth (modified from Aguilera et al., 2008).

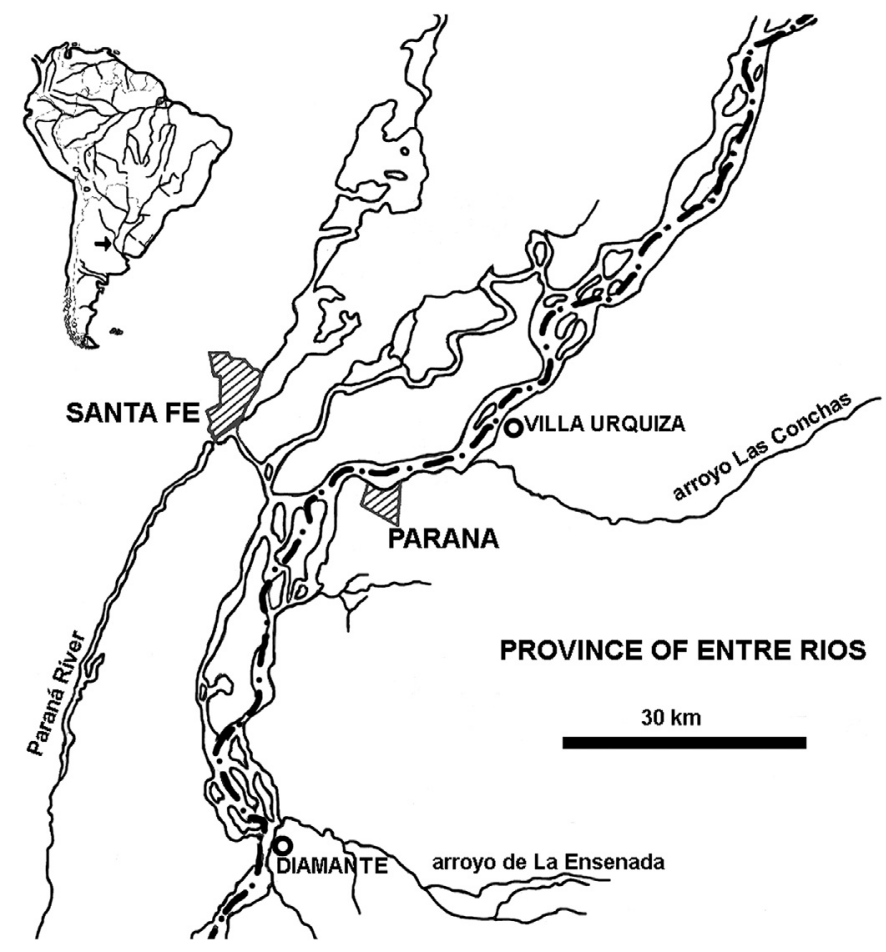

Fig. 1. Map of location. The arrow indicates the collecting site. [column fitting image]. 


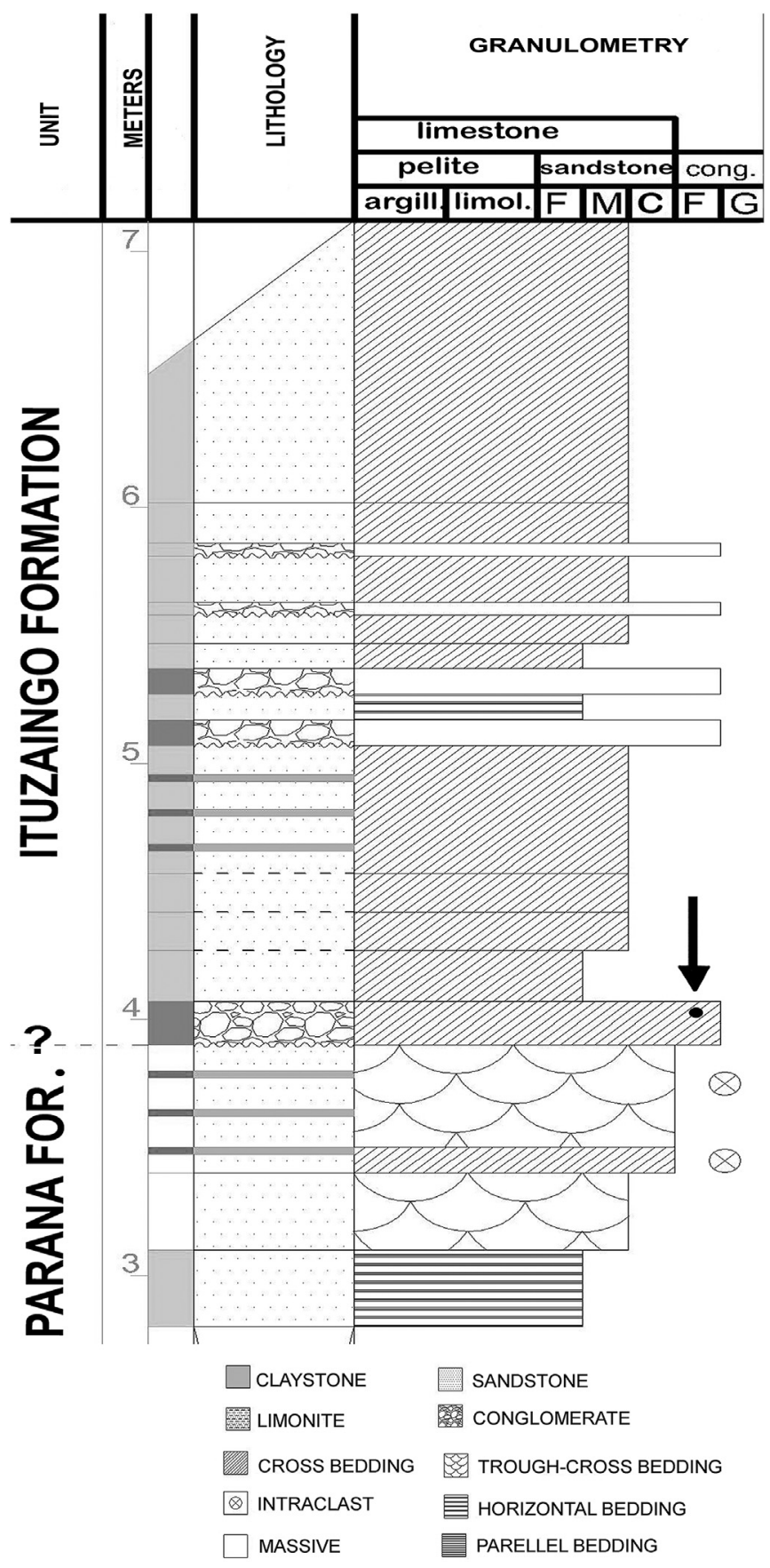

Fig. 2. Section at the Toma Vieja locality. The arrow indicates the level from which the specimens were collected. Meters indicate the height above the normal river level. [column fitting image].

\section{Phractocephalus ivy sp. nov.}

Holotype. MACN 14224-2: undistorted fragmentary posterior portion of neurocranium, with posteriormost part of frontals, fragments of both sphenotics, both pterotics and extrascapulae almost complete, anterior part of parietosupraoccipital, basioccipital, posterior part of parasphenoid, part of pterosphenoid, exoccipitals, prootics, and epioccipitals (Fig. 3 ).

Paratypes. MLP 86-V-1-1: fragment of cleithrum; fragments of opercle: MLP 92-III-5-1787, MLP 86-V-1-10; fragment of interopercle: MLP 92-III-1-12; fragments of lateral ethmoid: MLP 41-XII-
13-1038, MLP 92-III-4-53; fragments of parietosupraoccipital. MLP 92-III-4-51, MLP 86-V-1-3; fragment of sphenotic: MLP 86-V-1-6; fragment of postemporo-supracleithrum: MLP 86-V-1-2; fragments of pectoral spines: MLP 92-III-V-302a, MLP 86-V-1-11, MLP 92-III-V-302d.

Referred specimens. CICYTTP-PV-P 480, CICYyTTP-PV-P 588: skull roof fragments; MLP 86-V-1-4, MLP 86-V-1-5: fragments of parietosupraoccipital; MLP 92-III-5-302b; MLP 41-XII-13-1526; MLP 86-V-1-14: fragments of pectoral spine; MLP 92-III-5-302e-p; MLP 92-III-5-28/29; MLP 86-V-1-7; MLP 86-V-1-8; MLP 41-XII-131038; MLP 92-III-4-11: indeterminate skull fragments.

Etymology. Ivy, a word that means South in Guaraní language (Guaraní people inhabit parts of Paraguay, Bolivia, Uruguay, northeastern Argentina, and southern Brazil).

Diagnosis. Phractocephalus species differing from the type species of the genus in the skull-roofing bones ornamented with longitudinally elongate ridges and grooves along midline of frontals and parietosupraoccipital and from type species and the fossil species of genus in the presence of a very well-marked transversal (middle) pitline on parietosupraoccipital and partly in pterotics, and a posterior on extrascapulae. Besides, it differs from all species



Fig. 3. Phractocephalus ivy, holotype, MACN 14224-2, fragment of skull. 1, dorsal view of skull; 2 , ventral view of skull. Scale bar equals $1 \mathrm{~cm}$ [column fitting image] 
of the genus in the dentation pattern of pectoral spines with one anterior strong row and two posterior rows of more numerous and smaller dentations even in very large specimens. P. ivy sp. nov. also differs in the following character combination based on isolated bones: lateral ethmoid weakly expanded anteriorly but not laterally in such a way that orbital notch is visible from above, lateral wing of pterotic short, opercle ornamented with short grooves and ridges that radiate from the articular portion, very thick interopercle sparsely ornamented with thin ridges and shallow grooves, cleithrum with coarse ornamentation consisting mostly in grooves and some pits along ventral edge forming outward bulge or "shoulder" lateral to spine articulation, bulge of this "shoulder" terminating posterior to the level of articular socket of pectoral spines, pectoral spine ornamented with grooves and few pits and with a proximal sulcus without serrae in the posterior face.

Holotype description. There is no evidence of more than one species of Phractocephalus in the site. This is in agreement with that only one species was described in each fossil locality and that only one recent species is known. The preserved portion of skull roof is gently convex transversally but relatively flat in the midline at the height of the suture supraoocipital-frontals (Figs. 3 and 4). Skullroofing bones show the apomorphic ormanentation of Phractocephalus consisting in reticulating ridges and circular pits and longitudinally elongate ridges and grooves along midline of frontals and parietosupraoccipital. The ridges frequently align into lines that radiate out from the center of the bones. Pits concentrate in the center of the bones. The sutures between the skull roof bones are strong and straight or gently interdigitating. The posterior wall of skull does not show pterotic-epioccipital and paroccipital fossae. This is considered a plesiomorphic condition for pimelodids (Lundberg et al., 2012).

The holotype is medium sized for the genus. The transversal distance between both pterotic external margins is about $100 \mathrm{~mm}$. The depth of cranium between ventral margin of basioccipital and skull roof is $63 \mathrm{~mm}$. The anteriormost tip of prootic to posterior margin of basioccipital condyle is $73 \mathrm{~mm}$. The basioccipital is $35 \mathrm{~mm}$ long, measured from the condyle to the middle part of interdigitations between basioccipital and parasphenoid. Most of the other isolated bones in our sample correspond to fully grown specimens. The pit ornamentation appears to be apomorphic. This kind of ornamentation is characteristic of the recent $P$. hemioliopterus, but it is less evident in the fossil species.

A very well-marked transverse groove over the parietosupraoccipital and pterotics which corresponds to the middle pitline and another on extrascapulae represents the posterior pitline of more primitive teleosts (Fig. 3 ).

The basioccipital (Figs. 3 and 4) is a strong bone sutured with parasphenoid, prootic, and exoccipital. The suture with parasphenoid is very strongly interdigitated. The fossa for the ossified Baudelaut ligament is large. The articular facet for the complex vertebra is subcircular, little wider than deeper. The exoccipital (Figs. 3 and 4) sutures dorsally with parietosupraoccipital, epioccipital, and pterotic, laterally with prootic, and basally with basioccipital. Both exoccipitals widely suture in the midline to form the roof of the foramen magnum for the vagus and hypoglossus nerves. The parietosupraoccipita (Figs. 3 and 4). It is a large bone. The dorsal surface is convex transversally. A transverse sensory groove occurs posteriorly, at level of the suture pteroticextrascapula. The ornamentation is especially formed by rounded pits and parallel anteroposterior ridges in the middle of the bone.

The extrascapula (Figs. 3 and 4) is ovoid, plate-like, and suturing with the pterotic, parietosupraoccipital, and presumably, by the postemporal-supracleithrum which is missing in both specimens. The shape and position of extrascapular is similar to that of remaining species of Phractocephalus.

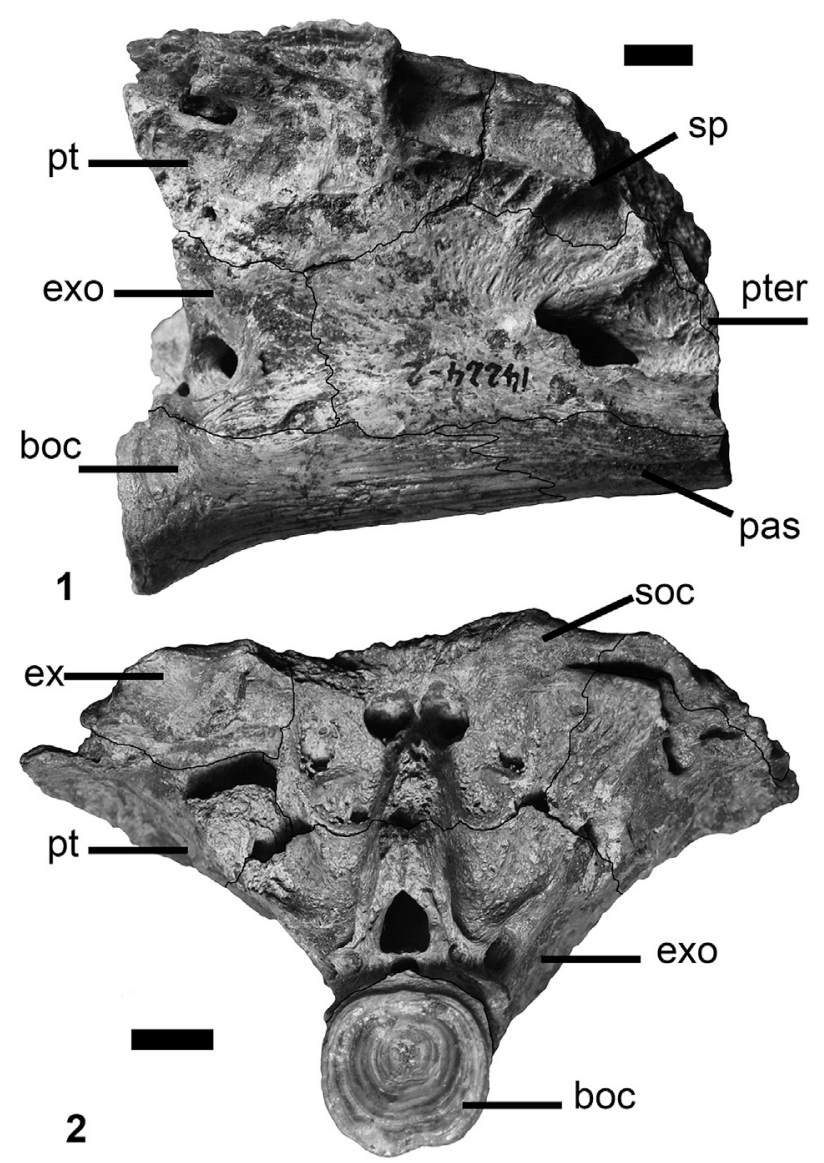

Fig. 4. Phractocephalus ivy, holotype, MACN 14224-2, fragment of skull. 1, lateral view; 2 , posterior view. Scale bar equals $1 \mathrm{~cm}$ [column fitting image].

The pterotic (Figs. 3 and 4) broadly sutures with the sphenotic, parietosupraoccipital, and extrascapula. Ventrolaterally it sutures with prootic and exoccipital. The bone has a short medium-sized angular wing projecting from the posterolateral corner which is clearly seen in dorsal view (Fig. 3). This angular wing is similar but shorter than that of the other Phractocephalus species. It is intermediate to that seen in Pseudoplatystoma (almost without wing) and Sorubimichthys (large wing).

The prootic (Figs. 3 and 4) is quadrangular. It forms greater part of the posterior lateral wall of neurocranium. It sutures with pterosphenoid, sphenotic, pterotic, epioccipital, exoccipital, basioccipital, and parasphenoid. A large trigeminofacial nerve foramen is bounded posteriorly by the prootic and anteriorly by the pterosphenoid. Only a posterior portion of the pterosphenoid (Figs. 3 and 4) bone was preserved.

The sphenotic is large, approaching a parallelogram in form, and sutured to frontal, parietosupraoccipital, and pterotic. The free lateral margin has a gently convex bulge but lacks postorbital process. The fossa for the articulation with the hyomandibula is large, anteroposteriorly oriented, and dorsoventrally curved. Only a posterior portion of sphenotic was preserved bordering the trigeminal nerve foramen (Figs. 3 and 4). One fragment of this bone is also figured (MLP 86-V-1-8; Figs. 3, 4 and 8.4).

Only the medial posteriormost part of frontals is preserved (Fig. 3). They suture laterally with sphenotics and posteriorly with parietosupraoccipital. They have many elongate ridges on the surface. The ornamentation is similar to that present in the other two fossil species.

A large number of isolated bones with the typical 
ornamentation were found and considered as paratypes. The descriptions of these bones are listed alphabetically.

Cleithrum (based on MLP 96-V-4-1; Fig. 5). The bone is coarsely ornamented, mostly with grooves and some pits along the ventral edge. That edge forms an outward bulge or "shoulder" lateral to spine articulation. The bulge of the "shoulder" terminates posteriorly to the level of articular socket of pectoral spines. In P. hemioliopterus, the cleithrum is pitted and in P. nassi it has grooves. The cleithrum of $P$. hemioliopterus lacks coarse ornamentation along the ventral edge of "shoulder". The bulge of the "shoulder" terminates posteriorly in line with termination of articular socket of pectoral spine in P. nassi. In P. acreornatus the cleithrum is unknown.

Interopercle. Based on MLP 92-III-1-12 (Fig. 6.3). The interopercle is very thick and scarsely ornamented with thin and shallow ridges and grooves. The posterior margin is fluted. The bone is robust as in $P$. acreornatus differing from the much more slender interopercle of $P$. hemioliopterus (the bone is unknown in $P$. nassi). The ornamentation of interopercle is intermediate between $P$. acreornatus and $P$. hemioliopterus.

Lateral ethmoid - (based on MLP 41-IV-13-1038 and MLP 92-III4-53; Fig. 7). The surface is slightly convex and strongly ornamented with rounded pits. The lateral edge was well preserved. The anterolateral margin is fluted. As the bone is not expanded laterally, the orbital notch is visible from above. The absence of lateral expansion with a well formed orbit notch is similar to $P$. hemioliopterus and differs from $P$. acreornatus and $P$. nassi. The weak anterior expansion is similar to that of $P$. nassi and differs from the other species.

Opercle. Based on MLP 92-III-5-1787 (Figs. 8.1 and 8.2). The bone is very thick in the articular area. The socket is oblong, large, and deep. The very coarse ornamentation is mainly represented by

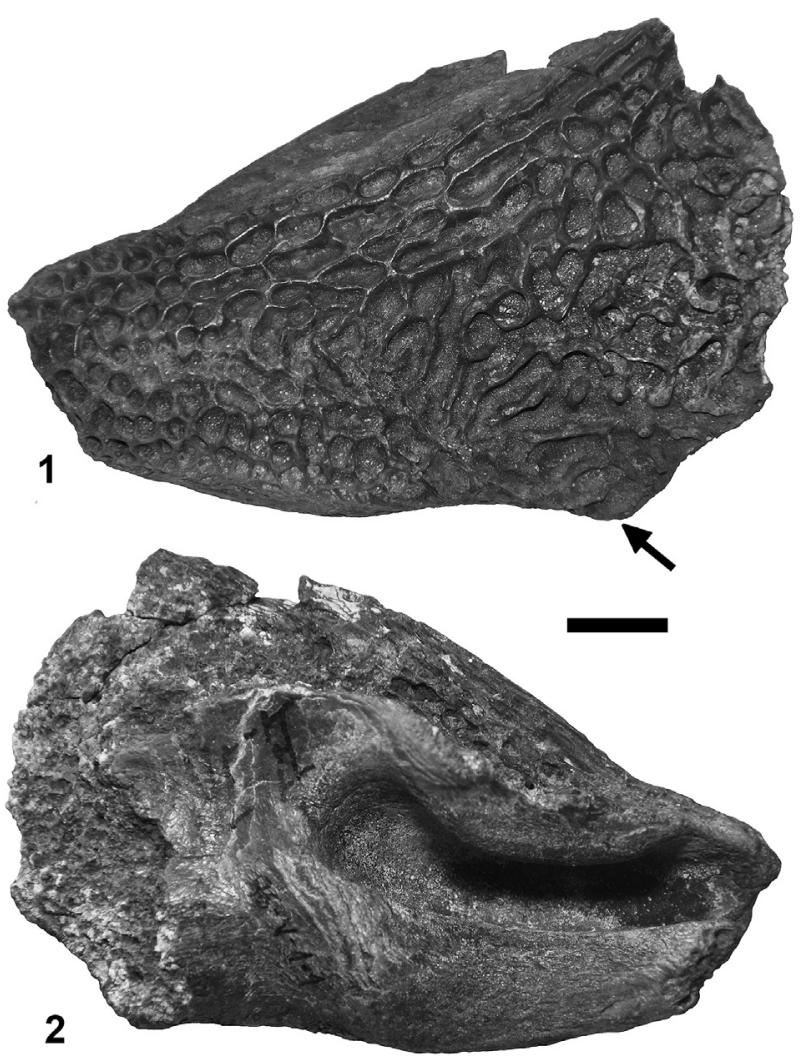

Fig. 5. Phractocephalus ivy, MLP 86-V-1-1, cleithrum. 1, external view (arrow indicates "shoulder"); 2 , internal view. Scale bar equals $1 \mathrm{~cm}$ [column fitting image]. short grooves and ridges that radiate from the articular portion. The dorsal margin forms an unormamented ledge. The ornamentation is similar to that of $P$. acreornatus and $P$. nassi and less coarse than that of $P$. hemioliopterus.

Postemporo-supracleithrum. Based on MLP 86-V-1-2 (Fig. 8.5). Only a large fragment of the external portion of the left supracleithrum is preserved. The anterior and proximal sections are missing. The coarse ornamentation consists of grooves anterioposteriorly oriented.

Parietosupraoccipital. Based on MLP 92-III-4-51and MLP 86-V-14 (Fig. 8.1-8.3). It is a large bone. The dorsal surface is convex transversally. The fragment MLP 92-III-4-51 has a concave posterior margin in dorsal view with an unornamented posterior projection forming a lap joint for the nuchal plate, also seen in MLP 86-V-1-. The ornamentation is formed by rounded pits of random distribution excepting in the anterior part where pits are anteroposteriorly elongate and in the posteriormost part, where pits and grooves are organized into two bands that follow the posterior concavity (Fig. 10). The posterior margin shape appears to be intraspecifically variable, at least in P. acreornatus (Aguilera et al., 2008) and P. hemioliopterus.

Pectoral spine. Based on MLP 92-III-5-302a, b, d, MLP 86-V-1-14 (Fig. 9). The pectoral spine shaft is robust and roughly quadrangular to ovoid in section. It is strongly ornamented with anastomosing ridges and grooves and very few pits (neither meshlike nor finelystriate). The anterior dentations are very strong, erect, and blunt. Some are transversely widened and others are round in section (Fig. 9.3). The posterior dentations are arranged into two rows (Fig. 9.3, 9.6, 9.7). There is no evidence of fusion between dentation of both hemitrichia even in very large specimens. They are half the size of the anterior ones and much more numerous. There is a sulcus in the proximal posterior face without serrae (MLP 92-III-V302b). The ornamentation is similar to that of $P$. nassi but differs from $P$. hemioliopterus and $P$. acreornatus where the ornamentation is mainly formed by pits. The dentation pattern with one anterior strong row and two rows of more numerous and smaller dentations appear to be unique for the genus.

\section{Discussion}

The holotype and paratypes clearly belong in Phractocephalus based on the texture of the dermal bones, pectoral girdle and fin spines extensively ornamented with a coarse meshwork of reticulating ridges surrounding rounded pits plus elongate ridges and sulci (Lundberg and Aguilera, 2003; Aguilera et al., 2008).

Three species of Phractocephalus are presently recognized: the living $P$. hemioliopterus, and the Miocene P. nassi Lundberg and Aguilera, 2003 and P. acreornatus Aguilera et al., 2008. Additionally, indeterminate Phractocephalus remains occur in the Honda Group of Colombia (Lundberg et al., 2010).

$P$. ivy differs from all the type species in the ornamentation of skull-roofing bones made of longitudinally elongate ridges and grooves along midline of frontals and parietosupraoccipital and from the fossil and living species of genus in the presence of a very well-marked transversal pitline on parietosupraoccipital. The ornamentation of holotype is similar to that found in young specimens of $P$. hemioliopterus (see Aguilera et al., 2008, Fig. 6c). The peculiar ornamentation of the recent $P$. hemioliopterus is unique within ostariophysans. Consequently, Miocene species appear to present an intermediate stage in a morphological gradient from a generalized ornamentation formed by ridges and grooves to one formed almost exclusively by pits. However, in some bones such as interopercle and pectoral spines, the ornamentation of Miocene species is stronger than in the recent one.

A remarkable feature is the occurrence of a transversal groove 

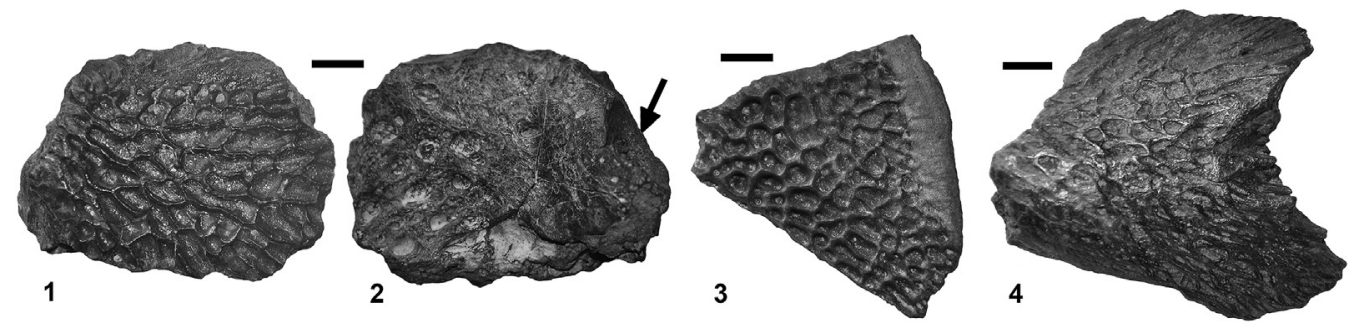

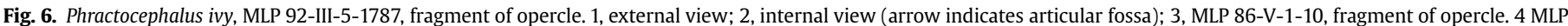
92-III-1-12, fragment of interopercle. Scale bar equals $1 \mathrm{~cm}$ [planned for page width].
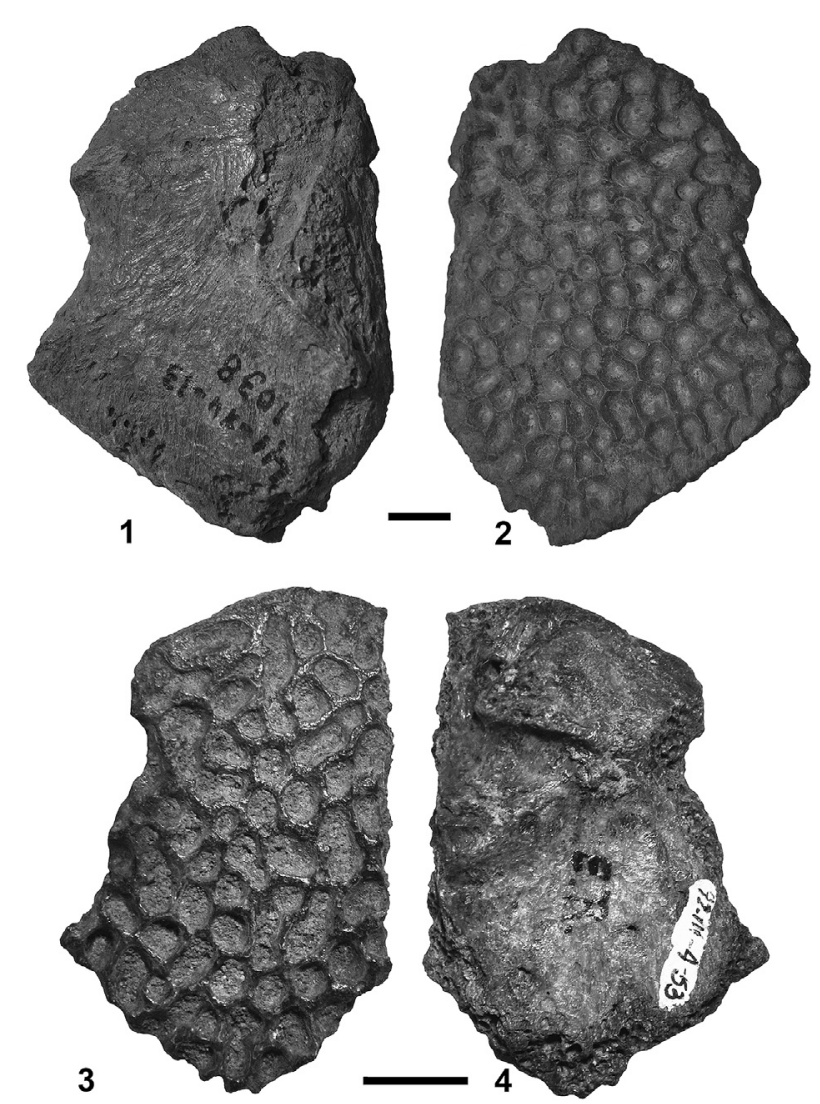

Fig. 7. Phractocephalus ivy, Fragments of lateral ethmoid. MLP 41-XII-13-1038, 1 internal view, 2 external view. MLP 92-III-4-53, 3 external view, 4 internal view. Scale bar equals $1 \mathrm{~cm}$ [column fitting image].

over the parietosupraoccipital and pterotics which corresponds to the middle pitline and another on extrascapulae. The pitline incised in bone is primitive for siluriforms and was discussed by Arratia and Gayet (1995). They described a middle pitline in two monospecific genera of the "family" Andinichthyidae which probably does not represent a monophyletic family (Arratia and Gayet, 1995) from the Paleocene of Bolivia. In the holotype of Incaichthys suarezi there is a well-marked transversal groove encompassing the parietosupraoccipital and at least one pterotic (the other pterotic is missing). In the better preserved holotype of Andinichthys bolivianensis there is a transversal groove in the parietosupraoccipital but not in the pterotics. However, there is an additional transversal groove in the extrascapulae. The parietosupraoccipital and pterotic grooves were interpreted as being the middle pitline and the extrascapular groove the posterior pitline (Arratia and Gayet, 1995). Middle pitlines on the parietosupraoccipital and pterotics also occur in genera of the family Doradidae (Sabaj Pérez et al., 2007; Fig. 10). The occurrence of a well-marked groove in P. ivy is here considered to be of taxonomic importance as to separate it from all known species of Phractocephalus. However, a slightly marked parietosupraoccipital transverse groove was observed in one juvenile specimen of $P$. hemioliopterus (J. Lundberg, personal communication; Fig. 10). Thus, probably, it may be present in the juveniles and absent in adult specimens of all Phractocephalus excluded P. ivy.

In the Ituzaingó Formation, there are several isolated bones well preserved that we considered as paratypes of P. ivy. They show similarities and differences with the previously known fossil and recent species. First of all, the dentation pattern of pectoral spines (one anterior strong row and two posterior rows of more numerous and smaller dentations) appears to be a unique character within Phractocephalus. Additionally, the Phractocephalus isolated bones from Paraná differ from type species in the moderate anterior projection of lateral ethmoid, the pterotic angular wing short, the robustness and ornamentation of interopercle, the presence of coarse ornamentation along ventral edge of "shoulder" in the cleithrum, and in the ornamentation of opercle, cleithrum, and interopercle. P. ivy differs from P. nassi because the lateral ethmoid does not have the expansion covering the orbit, the pterotic angular wing is short, and the lateral bulge of "shoulder" of cleithrum terminates posterior to the level of a rticular socket of pectoral spine.

\section{Associated fauna}

The "Conglomerado Osífero" provided remains of elasmobranchs (reworked marine sharks from the Paraná Formation and a few continental rays), teleosteans, crocodilians, chelonians, birds, and different groups of terrestrial and aquatic mammals (Cione et al., 2000). Along with the Phractocephalus remains, many described and undescribed teleosteans occur: catfishes (doradids, callichthyidse, loricariidse, pimelodids, ariids), characiforms (Cynodontidae indet., the Serrasalmidae Megapiranha paranensis Cione et al., 2009, the Anostominae Leporinus scalabrinii Bogan et al., 2012; the Characidae Salminus noriegai Cione et al., 2013a, perciforms (Sciaenidae indet.) (Arratia and Cione, 1996; Cione et al., 2013b). The authors of the present paper are currently studying the entire ichthyofauna of both Paraná and Ituzaingó formations.

\section{Biogeography}

Freshwater fish historical biogeography has been shaped by changes in topography and plate relationships, in river basins, and fluctuations in sea level. In South America, the evolution of the tropical freshwater fishes is not fully understood if southern basins are not analyzed (Arratia and Cione, 1996).

The recent species $P$. hemioliopterus inhabits large, lowland rivers in the Amazonas, Orinoco, Araguaia-Tocantins, and Essequibo 


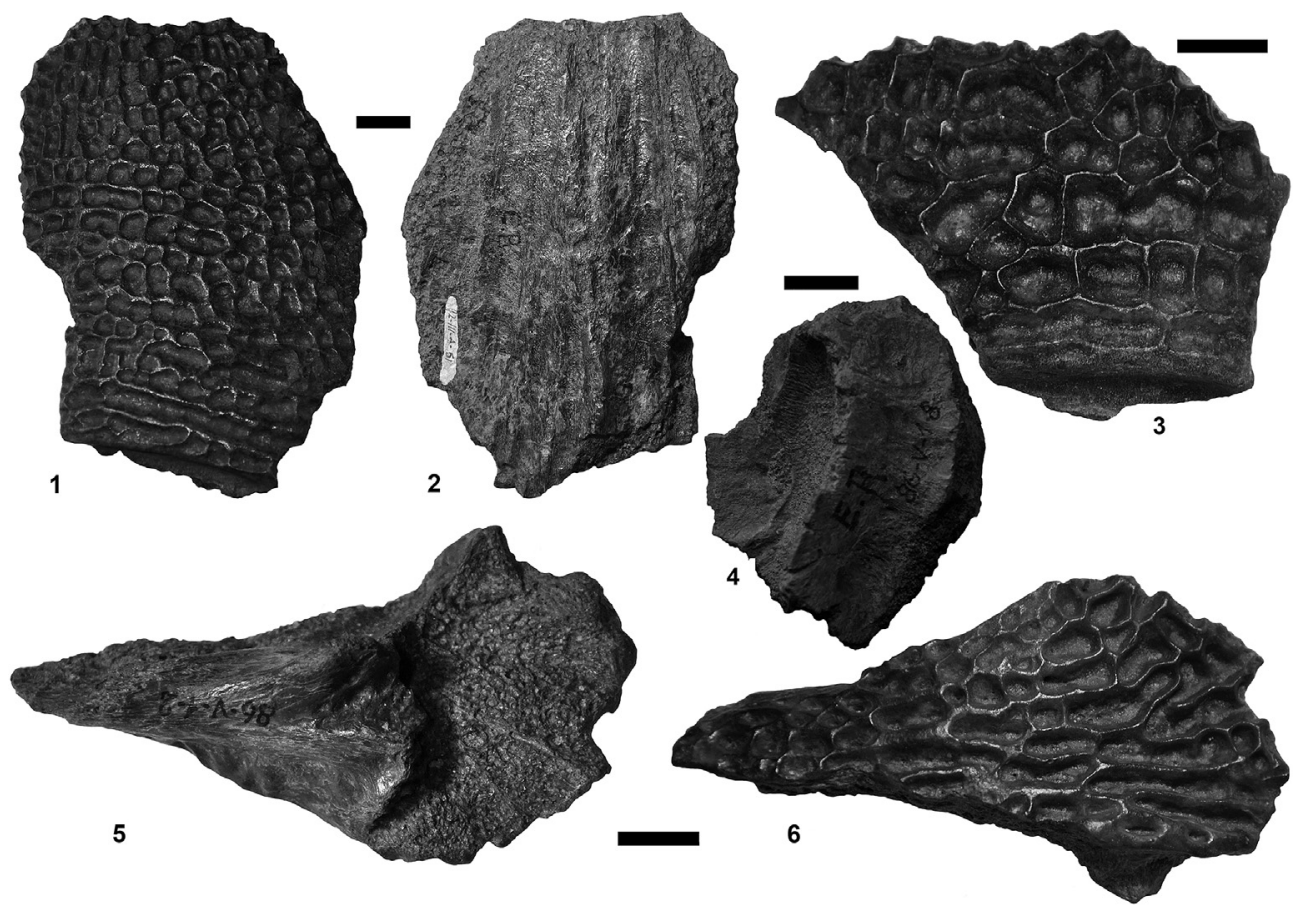

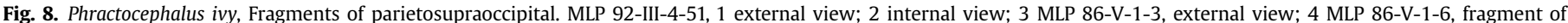
sphenotic, internal view; 5 MLP 86-V-1-2, fragment of postemporo-supracleithrum, internal view; 6 external view. Scale bar equals $1 \mathrm{~cm}$ [2 columns fitting image].

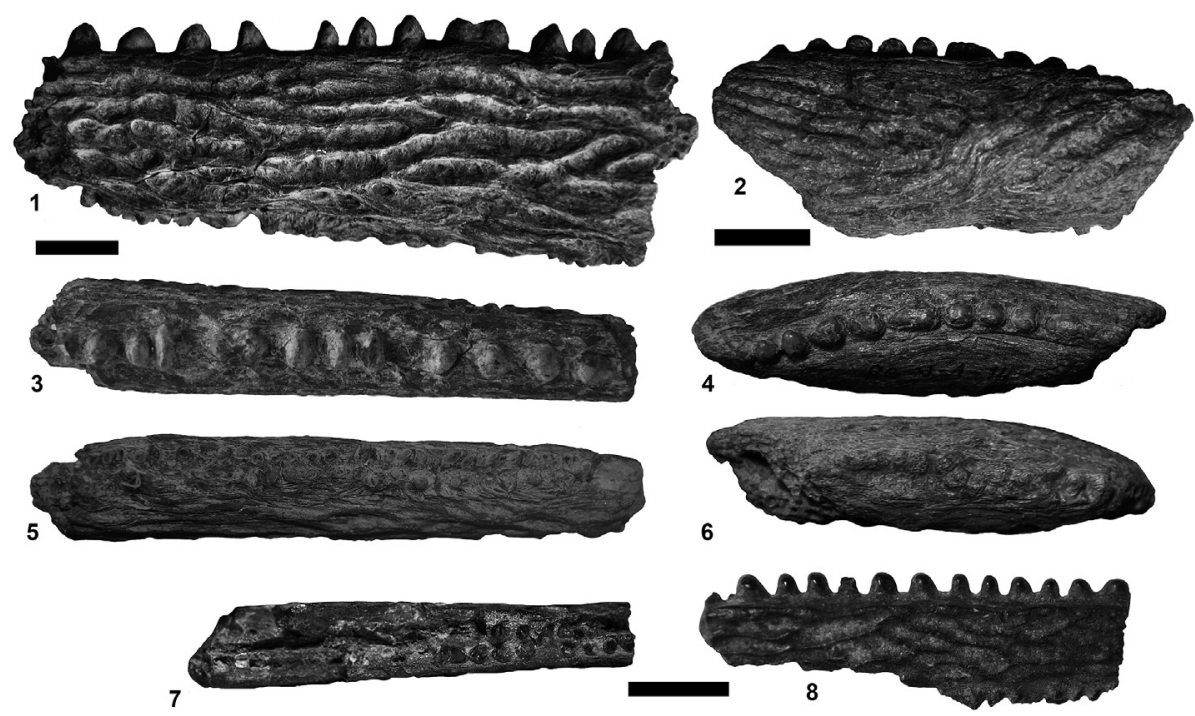

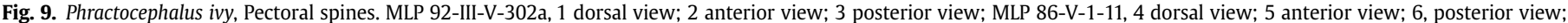
MLP 92-III-V-302d, 7 posterior view; 8 dorsal view. Scale bar equals $1 \mathrm{~cm}$ [2 columns fitting image].

basins and there are Miocene records of Phractocephalus in Colombia, western Brazil Venezuela (Fig. 11; Lundberg et al., 2010). We here recognize a new species of Phractocephalus in southern South America. This does not alter the obvious conclusion that this record suggests that: 1) an important hydrographic connection between the Paraná-Plata region and the Amazonian basin existed at least during the Tortonian and 2) the higher global temperatures of the Miocene permitted the occurrence of tropical taxa in southern South America (Cione et al., 2013b). Moreover, many different continental and marine taxa were distributed in even more southern latitudes in South America during the Miocene (e.g. characiforms in southern Chile, (Rubilar, 1994); loricariids and pimelodids in Argentinian Patagonia; Cione et al., 2005).

The extirpation of many of the tropical and subtropical fishes that inhabited the Paraguay-Paraná-Plata basin area is probably related to the global drop of temperatures that reduced the distribution of many organisms (Cione et al., 2013b; Zachos et al., 2001). The most deletereous times for these fishes should have been the glacial periods of the Pliocene-Pleistocene (Markwick, 1998). On the contrary, the interglacial temperatures in the northern Paraguay-Paraná basin were surely adequate to Phractocephalus and other tropical fishes.

The present divide between lowlands of the Amazon and Paraguay-Paraná-de la Plata basins corresponds to the Michicola 

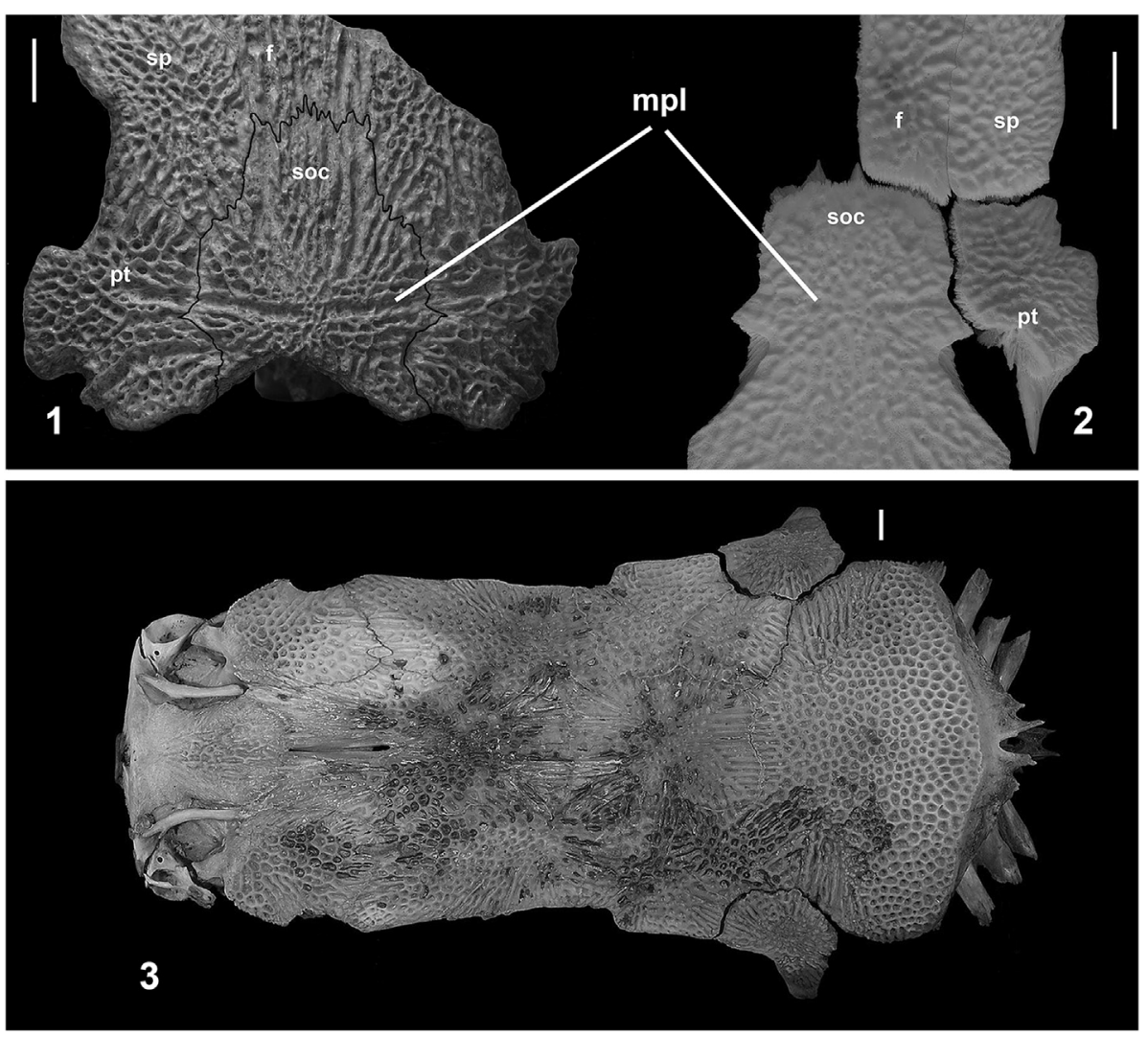

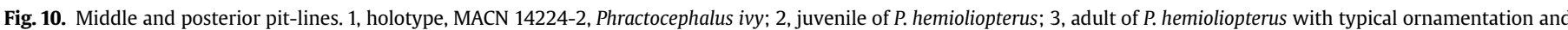
without pit-lines. Scale bar equals $1 \mathrm{~cm}$ [2 columns fitting image].
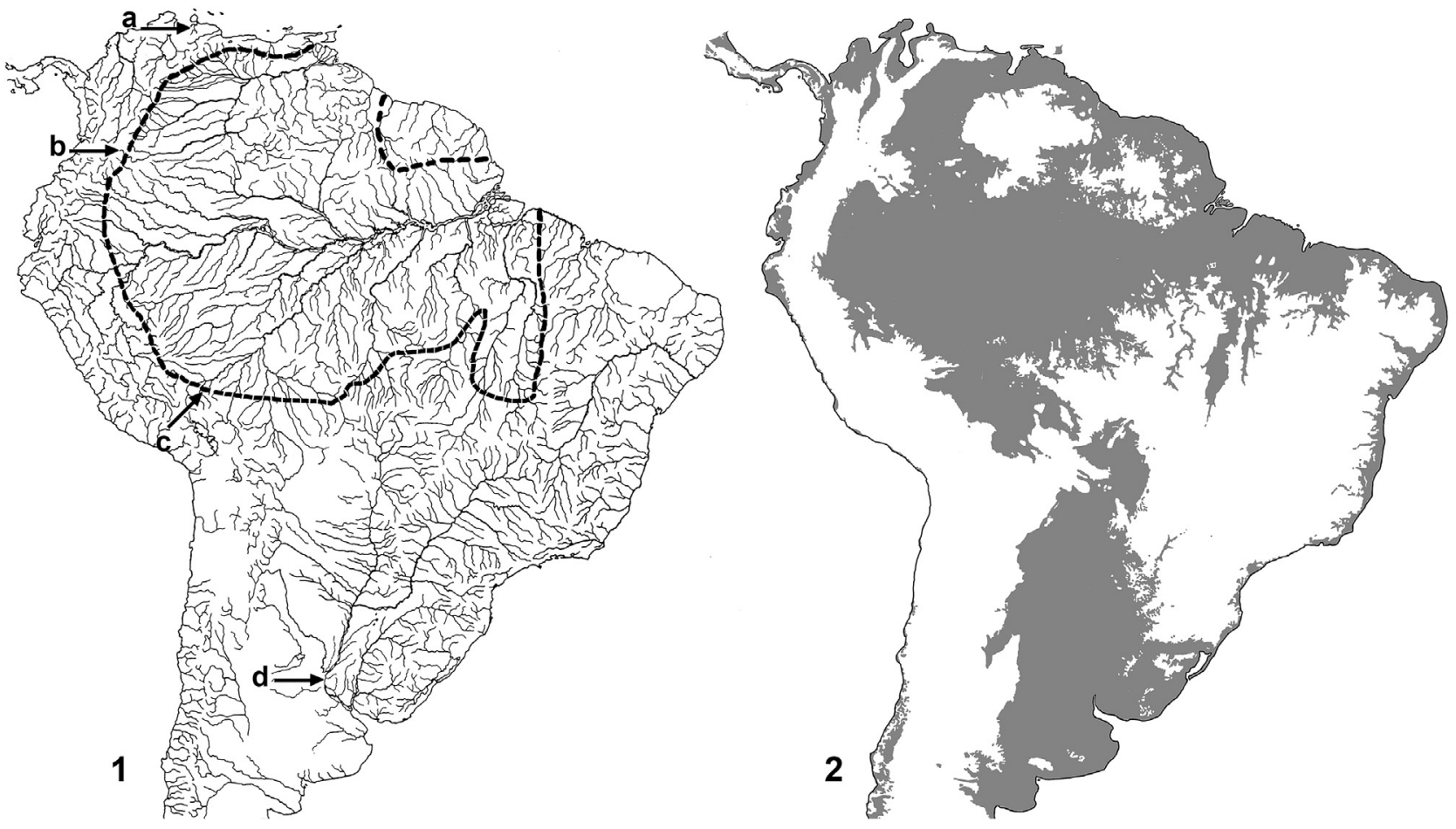

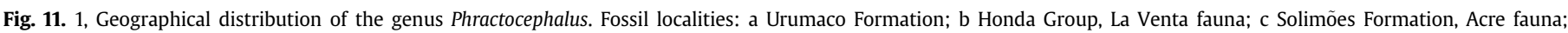

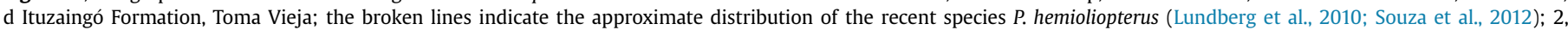

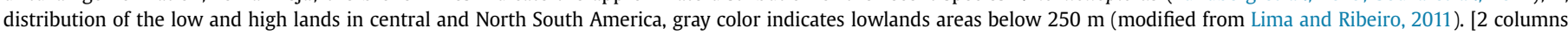
fitting image]. 
structural arch between the Andes and the Brazilian shield. The watershed between Amazon and Paraguay basins was regarded as a semipermeable divide for some fishes (Fig. 11.2; Carvalho and Albert, 2011). However, it apparently precluded re-population to the South of the extirpated lowland river inhabitant Phractocephalus species when temperature rose.

\section{Minimum age}

In most groups of Neotropical fishes, paleontological and biogeographic evidence suggest that adaptive diversification takes a long time and requires a lot of space (Albert et al., 2010; Lundberg et al., 2010). As is demonstrated by the present record, for Phractocephalus this diversification encompassed most of South America territory. The oldest Phractocephalus remains are known from Laventan ("Middle" Miocene) beds of the Honda Group in the Magdalena valley in Colombia dated at about 13.5-11.8 Ma (Madden et al., 1997). The undetermined remains of Honda Group provide a minimum age for the genus and its peculiar dermal ornamentation. The discovering of specimens attributable to the genus in sediments of ca. 9-6 Ma does not alter this minimal age.

\section{Conflict of interest}

The authors declare that no conflict of interest exists.

\section{Acknowledgments}

We thank the following institutions and individuals: Consejo Nacional de Investigaciones Científicas y Técnicas, Agencia Nacional de Promoción Científica y Tecnológica (PICT 913), Universidad Nacional de La Plata for permanent financial support. A. Kramarz, S. M. Alvarez, J. Lundberg, M. Sabaj, J. Noriega, B. Chernoff, H. Britski, and R. Vari for help with material under their care. J. Lundberg and K. Luckenbill for photographs of $P$. hemioliopterus. G. Arratia and J. Lundberg for suggestions and corrections in the manuscript. Jorge Noriega, D. Brandoni, L. Pérez, J. Casciotta, and J. Mennucci for assistance in the field.

\section{References}

Aceñolaza, F.G., 2000. La Formación Paraná (Mioceno medio): estratigrafía, distribución regional y unidades equivalentes. INSUGEO Ser. Correlación Geol. 14 $9-28$.

Aguilera, O., Bocquentin, J., Lundberg, J.G., Maciente, A., 2008. A new cajaro catfish (Siluriformes: Pimelodidae: Phractocephalus) from the late Miocene of southwestern amazonia and its relationship to $\dagger$ Phractocephalus nassi of the Urumaco formation. Paläeontol. Z. 82, 231-245.

Albert, J.S., Petry, P., Reis, R.E., 2010. Major Biogeographic and Phylogenetic Patterns. In: Albert, J.S., Reis, R.E. (Eds.), Historical Biogeography of Neotropical Freshwater Fishes. University of California Press, Berkeley, pp. 21-67.

Arratia, G., Gayet, M., 1995. Sensory canals and related bones of tertiary siluriform crania from Bolivia and North America and comparison with recent forms. J. Vert. Paleontol. 15, 482-505.

Arratia, G., Cione, A.L., 1996. The fish fossil record of southern South America Münchener Geowiss. Abh. 30A, 9-72.

Azpelicueta, M.M., Cione, A.L., 2011. Redescription of the Eocene catfish Bachmannic chubutensis (Teleostei: Bachmanniidae) of southern South America. J. Vert. Paleont. 31, 258-269.

Azpelicueta, M.M., Cione, A.L., Cozzuol, M.A., Mirande, J.M., 2015. Kooiichthys jono gen. et sp. nov, a primitive catfish (Teleostei, Siluriformes) from the marine Miocene of southern South America, in press J. Paleontol.

Berra, T., 2001. Freshwater Fish Distribution. Academic Press, London, p. 604.

Bogan, S., Sidlauskas, B., Vari, R.P., Agnolin, F., 2012. Arrhinolemur scalabrinii ameghino, 1898, of the late miocene-a taxonomic journey from the mammalia to the anostomidae (Ostariophysi: Characiformes). Neotrop. Ichthyol. 10, 555-560.

Brandoni, D., 2013. Los mamíferos continentales del "Mesopotamiense" (Mioceno tardío) de Entre Ríos, Argentina. Diversidad, edad y paleobiogeografía. In: Brandoni, D., Noriega, J.I. (Eds.), El Neógeno de la Mesopotamia Argentina. Publ. especial Asoc. Paleont, Argentina, pp. 179-191, 14.

Brunetto, E., Noriega, J.I., Brandoni, D., 2013. Sedimentología, estratigrafía y edad de la Formación Ituzaingó en la provincia de Entre Ríos, Argentina. In: Brandoni, D.
Noriega, J.I. (Eds.), El Neógeno de la Mesopotamia Argentina. Publ. especial Asoc. Paleont, Argentina, pp. 13-27, 14.

Carvalho, T.P., Albert, J.S., 2011. The amazon-paraguay divide. In: Albert, J.S., Reis, R.E. (Eds.), Historical Biogeography of Neotropical Freshwater Fishes. University of California Press, Berkeley, pp. 193-202.

Cione, A.L., Azpelicueta, M.M., Bond, M., Carlini, A.A. Casciotta, J.R., Cozzuol, M.A., de la Fuente, M., Gasparini, Z., Goin, F.J., Noriega, J., Scillato-Yané, G.J., Soibelzon, L., Tonni, E.P., Verzi, D., Vucetich, M.G., 2000. The Miocene vertebrates from Paraná, eastern Argentina. In: Aceñolaza, F.G., Herbst, R. (Eds.), El Neógeno de Argentina. Serie Correlación Geológica, pp. 191-237, 14.

Cione, A.L., Dahdul, W., Lundberg, J.G., Machado-Allison, A., 2009. Megapiranha paranensis, a new genus and species of Serrasalmidae (Characidae, Teleostei) from the upper Miocene of Argentina. J. Verteb. Paleontol. 29, 350-358.

Cione, A.L., Tonni, E.P., 2005. Bioestratigrafía basada en mamíferos del Cenozoico superior de la región pampeana. In: de Barrio, R., Etcheverry, R., Caballé, M., Llambías, E. (Eds.), Geología y Recursos Minerales de la Provincia de Buenos Aires. Relatorio del XVI Congreso Geológico Argentino, XI, La Plata, pp. 193-200.

Cione, A.L., Azpelicueta, M., de las, M., 2013a. The first fossil species of Salminus, a conspicuous South American freshwater predatory fish (Teleostei, Characiformes), found in the Miocene of Argentina. J. Verteb. Paleontol. 33, 1051-1060.

Cione, A.L., Cabrera, D.A., Azpelicueta, M.M., Casciotta, J.R., Barla, M.J., 2013b. Peces del Mioceno marino y continental de Entre Ríos, Oriente central de Argentina. In: Brandoni, D., Noriega, I.J. (Eds.), El Neógeno de la Mesopotamia Argentina. Publ. Esp. Asoc. Paleont, Argentina, pp. 71-83, 14.

Cione, A.L., Azpelicueta, M.M., Casciotta, J.R., Dozo, M.T., 2005. Tropical freshwater teleosts from Miocene beds of eastern Patagonia, southern Argentina. Geobios 38, 29-42.

Eschmeyer, W.N., Fong, J.D., 2015. Catalog of Fishes. Accessed October 2015. http:// research.calacademy.org/research/ichthyology/catalog/SpeciesByFamily.asp.

Grande, L., 1987. Redescription of Hypsidoris farsonensis (Teleostei: Siluriformes), with a reassessement of its phylogenetic relationships. J. Vert. Paleontol. 7, 24-54.

Lima, F.C.T., Ribeiro, A.C., 2011. Continental-Scale Tectonic Controls of Biogeography and Ecology. In: Albert, J.S., Reis, R.E. (Eds.), Historical Biogeography of Neotropical Freshwater Fishes. University of California Press, Berkeley, pp. 145-164.

Lowe-McConnell, R.H., 1987. Ecological Studies in Tropical Fish Communities. Cambridge University Press, Cambridge, p. 382.

Lundberg. J.G. Aguilera, O., 2003. The late Miocene Phractocephalus catfish (Siluriformes: Pimelodidae) from Urumaco, Venezuela: additional specimens and reinterpretation as a distinct species. Neotrop. Ichthyol. 1, 97-109.

Lundberg, J.G., Cobain, R., Sullivan, J.P., Fisch-Muller, S., 2012. Phylogenetic position and notes on the natural history of Pimelabditus moli Parisi \& Lundberg, 2009 (Teleostei: Siluriformes), a recently discovered pimelodid catfish from the Maroni River basin. Cybium 36, 105-114.

Lundberg, J.G., Littman, M., 2003. Pimelodidae (Long-Whiskered Catfishes). In: Reis, R.E., Kullander, S.O., Ferraris Jr., C.J. (Eds.), Checklist of the Freshwater Fishes of South and Central America. EDIPUCRS, Porto Alegre, pp. 432-446.

Lundberg, J., Sabaj Pérez, M.H., Dahdul, W.M., Aguilera, O., 2010. The Amazonian Neogene Fish Fauna. In: Hoorn, C., Wesselingh, F. (Eds.), Amazonia: Landscape and Species Evolution. A Look into the Past. Wiley-Blackwell, Chichester, pp. $281-300$.

Madden, R.H., Guerrero, J., Kay, R., Flynn, J.J., Swisher III, C.C., Walton, A.H., 1997. The laventan stage and age. In: Kay, R., Madden, R., Cifelli, R., Flynn, J. (Eds.), Vertebrate Paleontology in the Neotropics. The Miocene Fauna of La Venta. Smithsonian Institution Press, Colombia. Washington D.C., pp. 499-519

Malabarba, M.C., Malabarba, L., 2010. Biogeography of Characiformes: an evaluation of the available information of fossil and extant taxa. In: Nelson, J.S., Schultze, H.P., Wilson, M.V.H. (Eds.), Origin and Phylogenetic Interrelationships of Teleosts. Verlag Dr. Friedrich Pfeil, München, pp. 317-336.

Markwick, P.J., 1998. Fossil crocodilians as indicators of Late Cretaceous and Cenozoic climates: implications for using palaeontological data in reconstructing palaeoclimate. Palaeog. Palaeoclimatol. Palaeoecol. 137, 205-271.

Pérez, L.M., 2013. Nuevo aporte al conocimiento de la edad de la Formación Paraná, Mioceno de la provincia de Entre Ríos, Argentina. In: Brandoni, D., Noriega, J.I. (Eds.), El Neógeno de la Mesopotamia Argentina. Pub. especial Asoc. Paleont, Argentina, pp. 7-12, 14

Rubilar, A., 1994. Diversidad ictiológica en depósitos continentales miocenos de la Formación Cura-Mallin, Chile $\left(37^{\circ}-39^{\circ} \mathrm{S}\right)$ : implicancias paleogeográficas. Rev. Geol. Chile 21, 3-29.

Sabaj Pérez, M.H., Aguilera, O.A., Lundberg, J.G., 2007. Fossil catfishes of the families Doradidae and Pimelodidae (Teleostei: Siluriformes) from the Miocene Urumaco Formation of Venezuela. Proc. Acad. Nat Sci. Phila. 156, 157-194.

Scasso, R.A., McArthur, J.M., del Río, C., Martínez, S., Thirlwall, M.F. $2001{ }^{87} \mathrm{Sr} /{ }^{86} \mathrm{Sr}$ late Miocene age of fossil molluscs in the "Entrerriense" of the Valdés Peninsula (Chubut, Argentina). J. South Am. Earth Sci. 14, 319-329.

Souza, C.A., Hashimoto, D.T., Pereira, L.H., Oliveira, C., Foresti, Porto-Foresti, F., 2012 Development and characterization of microsatellite loci in Phractocephalus hemioliopterus (Siluriformes: Pimelodidae) and their cross-species amplification in six related species. Conserv. Gen. Res. 4, 499-501.

Spix von, J.B., Agassiz, L., 1829. Selecta genera et species piscium quos in itinere per Brasiliam annos MDCCCXVII-MDCCCXX jussu et auspiciis Maximiliani Josephi I... colleget et pingendso curavit Dr J. B. de Spix. Monachii. Part 1, 1-82. 
Taylor, W., Van Dyke, G., 1985. Revised procedures for staining and clearing small fishes and other vertebrates for bone and cartilage. Cybium 9, 107-119.

Uba, C., Hasler, C.A., Buatois, L., Schmitt, A., Plessen, B., 2009. Isotopic, paleontologic, and ichnologic evidence for late Miocene pulses of marine incursions in the central Andes. Geology 37, 827-830.

Zachos, J., Pagani, M., Sloan, L., Thomas, E., Billups, K., 2001. Trends, rhythms and aberrations in global climate 65 Ma to Present. Science 292, 686-693. 